\title{
Wajah Pluralis, Feminis, dan Puitis dalam Tafsir Karya Djohan Effendi
}

(Pluralist, Feminist, and Poetic Faces in Djohan Effendi's Tafsir)

\section{Mukhamad Saifunnuha}

Sekolah Pascasarjana UIN Syarif Hidayatullah Jakarta

nuha.sayfun@gmail.com

DOI: $10.29240 /$ alquds.v4i2.1844

Submitted: 2019-07-29 | Revised: 2020-08-18 | Accepted: 2020-09-07

\begin{abstract}
The books of tafsir, which originally appeared in the Middle East, spawn extensively to many countries including Indonesia. One of the contemporary Indonesian tafsir is 'Pesan-Pesan al-Qur'an' by Djohan Effendi, which deserves to receive researchers' and academics' attention because of its uniqueness. Hence, this research aims to study and analyze this tafsir's book in terms of both methodological aspect and book's contents. The author uses the 'Four Methods' theory from AlFarmawiy and also Islah Gusmian's concept for the methodological analysis. Finally, by some analysis and discussion, this research finds that Djohan's tafsir uses the ijmâli method combined with the thematic method. While in the contents of the book, this tafsir has 3 major tendencies, namely pluralist, feminist, and poetic.
\end{abstract}

Keywords: Indonesian Tafsir, Pluralist, Feminist, Poetic

Abstrak. Sejak masa Nabi sampai dengan hari ini, karya-karya tafsir terus bermunculan, bukan hanya di tanah Arab, tetapi di seluruh penjuru dunia, termasuk Indonesia. Djohan Effendi dengan karya tafsirnya yang berjudul 'Pesan-Pesan alQur'an' menjadi salah satu karya tafsir Indonesia yang patut dikaji dan diperhatikan keberadaannya. Oleh karena iti, penelitian ini bermaksud untuk melakukan analisis terhadap karya tafsir tersebut, baik dari aspek metodologis maupun muatan tafsirnya. Teori 4 metode tafsir al-Farmawiy akan penulis gunakan untuk menganalisis aspek metodologinya, berbarengan juga dengan menerapkan model analisis karya tafsir 'ala' Islah Gusmian. Hasil dari penelitian ini menunjukkan bahwa metode yang digunakan Djohan dalam karya tafsir tersebut adalah metode ijmâli yang digabungkan dengan metode tematik sekaligus. Adapun kecenderungan utama yang terlihat dalam karya tafsir Djohan Effendi tersebut adalah pluralis, feminis, dan puitis.

Kata Kunci: Tafsir Indonesia, Pluralis, Feminis, Puitis 


\section{Pendahuluan}

Hadirnya al-Qur'an di tengah-tengah umat, secara langsung melahirkan karya-karya tafsir sebagai hasil penjelasan dan penafsiran atas ayat-ayatnya. Bukan hanya satu, tapi beragam karya tafsir telah eksis dengan model dan kecenderungannya masing-masing, sejak era klasik hingga kontemporer saat ini. ${ }^{1}$ Lebih dari itu, kajian tafsir yang semula hanya berpusat di tanah Arab saja, kemudian berkembang dan mendunia dimana umat Muslim berada, termasuk Indonesia.

Kajian tafsir di Indonesia bermula pada abad ke-16 dengan ditemukannya naskah tafsir surah al-Kahfi yang berada di Cambridge University. ${ }^{2}$ Setelah itu muncul kitab tafsir Turjumân al-Mustafî̀d karya Abd Rauf as-Singkili, dan begitu juga Tafsîr Marah Labîd (Tafsîr al-Munîr) karya Imam Nawawi al-Bantani, yang selanjutnya kedua kitab tafsir ini digolongkan pada tafsir klasik Indonesia (awal abad 17 -akhir abad 19). Adapun kitab-kitab tafsir yang lahir setelahnya disebut sebagai kitab tafsir modern Indonesia (paruh pertama abad ke-20 - akhir tahun 1980-an), seperti Tafsir al-Qur'an al-Karim Mahmud Yunus, Tafsir al-Azhar karya HAMKA, Tafsir al-Bayan karya Hasbi ashShiddiqiey, dan sebagainya. Sedangkan periode tafsir kontemporer Indonesia berawal pada tahun 90-an sampai dengan sekarang. ${ }^{3}$ Kajian tafsir di Indonesia dalam 3 periode tersebut telah dilakukan oleh para peneliti dan akademisi, baik lokal maupun internasional. Baik kajian yang bersifat analisis sebuah kitab tafsir maupun kajian holistik dalam satu periode seperti yang dilakukan oleh Federspiel dan Islah Gusmian dalam karya mereka. ${ }^{4}$

${ }^{1}$ Adz-Dzahabi memetakan tafsir berdasarkan 3 hal; (1) Berdasarkan sejarah perjalanan tafsir nya (marbalah at-tafsîr), terdapat 3 masa yaitu Tafsir pada masa Nabi dan Sahabat, Tafsir pada masa Tabi'in, dan Tafsir pada masa Kodifikasi; (2) Berdasarkan madzhab atau aliran nya, terdapat tafsir madzhab Syi'ah, Tafsir Khawarij, Tafsir Sufi, Tafsir Falsafi, Tafsir Fiqhi, dan Tafsir 'Ilmi; (3) Berdasarkan kecondongannya pada masa modern, terdapat corak 'Imi, Madz̧̧abi, 'Ilbadi, dan Adabi Ijtima'i. Lihat: Muhammad Husain Adz-Dzahabi, At-Tafsîr wa alMufassirûn (Kairo: Maktabah Wahbah, 1976).

${ }^{2}$ Anthony H. Johns, 'Qur'anic Exegesis in the Malay World: In Search of a Profile', in Approaches to the History of the Interpretation of the Qur'an, ed. by Andrew Rippin (Oxford: Clarendon Press, 1988), hlm. 257.

${ }^{3}$ Cucu Surahman, 'Pergeseran Pemikiran Tafsir Di Indonesia: Sebuah Kajian Bibliografis’, Afkaruna, 10.2 (2014), 219 < https://doi.org/10.18196/AIIJIS.2014.>.

${ }^{4}$ Kajian tafsir Indonesia paling awal dilakukan oleh para Indonesianis seperti AH Johns, Peter G Riddell, Federspiel, dan sebagainya. Lihat: Peter G. Riddell, 'Abdurra'uf AlSinkili's Tarjunān Al-Mustafìd: A Critical Study of His Treatment of Juz 16' (Australia Natoinal University, 1984); Johns, 'Qur'anic Exegesis in the Malay World: In Search of a Profile'; Peter G. Riddell, 'Earliest Quranic Exegetic Activity in the Malay Speaking States', Archipel, 38.1 (1989), 107-24 <https://doi.org/10.3406/arch.1989.2591>; Howard M. Federspiel, Popular Indonesian Literature of the Qur'an (New York: Cornell Modern Indonesia Project, 1994). 
Salah satu karya tafsir Indonesia pada periode kotemporer yang patut diapresiasi kehadirannya adalah karya tafsir karya Djohan Effendi yang berjudul Pesan-Pesan Al-Quran; Mencoba Mengerti Intisari Kitab Suci. Karya tafsir yang terbit pada tahun 2012 tersebut mempunyai ciri khas dan keunikan tersendiri dibandingkan kitab-kitab tafsir lainnya. Tidak banyak kajian yang dilakukan terhadap karya tafsir ini, kecuali beberapa penelitian saja, semisal penelitian yang dilakukan oleh Hammam Faizin dan Arsyad Sobby Kesuma dalam artikel mereka yang berjudul Pemikiran Tafsir Djohan Effendi. Sayangnya, artikel tersebut hanya sebatas menganalisis karya tafsir tersebut dari segi metodologinya saja, dan tidak melakukan analisis terhadap pemikiran tafsir Djohan. ${ }^{5}$ Berbeda dengan penelitian Hammam, Umi dalam penelitiannya mencoba melakukan telaah penafsiran tafsir Djohan terhadap surah al-Fatihah. Sumber utama penelitian tersebut tentu adalah karya tafsir Djohan itu sendiri. Berdasarkan penelitiannya, disimpulkan bahwa Djohan menggarisbawahi dan menekankan 4 kosakata yang ada dalam surah al-Fâtihah, yaitu Rabb, ar-Rabmân, ar-Rabîm, dan al-Mâlik, dimana pemaknaan Djohan terhadap keempat kata tersebut cenderung berbeda dari kebanyakan ulama. ${ }^{6}$

Pengamatan dan pembahasan yang cukup menarik tentang karya tafsir Djohan Effendi ini tersaji dalam acara 'Kupas Buku Pesan-Pesan al-Qur'an' bersama Prof. Dr. Jalaluddin Rakhmat dan Novriantoni Kahar, yang kemudian hasil diskusi tersebut ditulis oleh Evi Rahmawati dan dimuat dalam situs Islam Lib. Jalaluddin menyoroti beberapa hal ketika membahas karya tafsir ini, salah satunya adalah keindahan bahasa yang dihadirkan Djohan dalam karyanya tersebut. Beberapa kritik juga tidak lepas dari pandangannya, seperti susahnya seorang Da’i jika ingin mengutip dalam karya tafsirnya atas penjelasan sebuah ayat. Jalaluddin juga menkritisi tentang tema-tema yang disajikan Djohan, dimana menurutnya terdapat tema-tema penting yang dilewatkan Djohan dalam tafsirnya. Sedangkan itu Novri melakukan analisis mengenai posisi Djohan dengan karya tafsirnya tersebut terhadap al-Qur'an itu sendiri. Menggunakan konsep yang dikemukakan oleh Farid Essack tentang beberapa macam persentuhan manusia dengan al-Qur'an, Novri kemudian mendudukkan Djohan

${ }^{5}$ Hamam Faizin and Arsyad Sobby Kesuma, 'Pemikiran Tafsir Djohan Effendi', Kalam, 11.2 (2017), 455-88 <https://doi.org/10.24042/klm.v11i2.1360>.

${ }^{6}$ Umi Nuriyatur Rohman, 'Tafsir Surah Al-Fatihah (Telaah Atas Pesan-Pesan AlQur'an: Mencoba Mengerti Intisari Kitab Suci Karya Djohan Effendi)', Jurnal Ilmu Al-Qur'an Dan Hadist, 1.2 (2018), 211-38 < https://doi.org/10.1017/CBO9781107415324.004>. 
dengan karya tafsirnya sebagai scholarly lover atau pecinta ilmiah, yang ingin menunjukkan keindahan dan keagungan al-Qur'an.

Selain tulisan-tulisan diatas, memang banyak penelitian yang mengkaji pemikiran Djohan, namun bukan pemikiran tafsirnya, melainkan dari sisi argumentasi pluralisnya. Salah satunya adalah penelitian yang dilakukan oleh Rifat dan Alvin, yang mengkaji konsep pluralisme dalam pandangan Djohan Effendi. Peneliti memandang bahwa pluralisme merupakan sebab atas wujudnya agama yang beragam dengan konsepnya masing-maing. Terlebih di Indonesia, pluralisme menjadi sebuah keniscayaan dalam kajian karena masyarakat Indonesia yang sifatnya majemuk, baik agama, bahasa, ras dan budaya. Hasil penelitian menunjukkan bahwa Djohan sebagai salah satu tokoh pluralis Indonesia memandang 'Agama yang dipahami manusia' sebagai sesuatu yang nisbi. Oleh karena itu, kebenaran yang dikemukakan manusia atas nama Agama adalah sifatnya nisbi, karena manusia itu sendiripun bersifat nisbi. Sedangkan yang absolut adalah kebenaran Agama itu sendiri yang berasal dari-Nya. ${ }^{8}$

Senada dengan itu, Umi Hanik dalam tulisannya yang mengkaji pluralisme Agama juga tidak luput menyebut Djohan dengan segala pemikirannya tentang pluralisme agama, berbarengan juga dengan tokoh-tokoh lain seperti Nurcholis Majid, Mukti Ali, M. Rasjidi, Abdurrahman Wahid (Gus Dur), dan Alwi Shihab. ${ }^{9}$ Sebagaimana juga pemikiran pluralis Djohan tergambar dalam artikel yang dimuat oleh tirto.id, yang mengangkat bagaimana tegasnya Djohan dalam membela agama yang tertindas, salah satunya yaitu golongan Ahmadiyah Lombok yang mengalami penyerangan di pemukiman mereka. Kegelisahannya tersebut tertuang dalam sebuah esai yang diunggah di laman Gerakan Ahmadiyah Indonesia (GAI). Oleh sebab itulah Djohan dikenal sebagai tokoh penggiat Islam inklusif, plural, dan liberal yang paling konsisten di Indonesia, sekaligus tokoh pembaharu Islam Indonesia bersama tokoh-tokoh pembaharu lainnya. ${ }^{10}$

Beberapa artikel yang penulis sebut diatas secara umum telah menyajikan informasi yang menarik, utamanya terkait pemikiran Djohan. Namun dari sekian tulisan tersebut, belum ada yang mengkaji karya tafsir

${ }^{7}$ Evi Rahmawati, 'Membaca "Pesan-Pesan Al-Qur'an” Karya Djohan Effendi', Islam Lib, $2012<$ http://islamlib.com/kajian/quran/membaca-pesan-pesan-al-quran-karya-djohaneffendi/>.

${ }^{8}$ Rif at Husnul Ma'afi and Alvin Qodri Lazuardy, 'Concept of Religious Pluralism According To Djohan Effendi', YAQZHAN: Analisis Filsafat, Agama Dan Kemanusiaan, 5.2 (2019), 87-102 <https://doi.org/https://doi.org/10.24235/jy.v5i2.5708>.

'Umi Hanik, 'Pluralisme Agama Di Indonesia', Jurnal Pemikiran Keislaman, 25.1 (2014), 44-63 < https://doi.org/10.33367/tribakti.v25i1.154>.

${ }^{10}$ Akhmad Muawal Hasan, 'Djohan Effendi Dan Warisan Islam Yang Toleran', Tirto.Id, $2018<$ https://tirto.id/djohan-effendi-dan-warisan-islam-yang-toleran-cKYk>. 
Djohan berdasarkan dua aspek sekaligus, yaitu dari aspek metodologinya serta isi kandungan tafsirnya, sedangkan kedua aspek tersebut merupakan hal penting yang seringkali menjadi pembahasan diantara para pengkaji dan peneliti tafsir. Disisi lain, fakta bahwa tafsir karya Djohan Effendi ini hadir ditengah-tengah masyarakat Indonesia, tentu tidak bisa dinafikan dan diabaikan begitu saja. Sedangkan itu, peneliti yang mengangkat penafsiran Djohan dalam kajian mereka juga tergolong masih sedikit, yang artinya karya tafsir ini belum begitu banyak mendapat perhatian, baik dari akademisi, peneliti, maupun masyarakat awam pada umumnya. Sehingga penelitian ini kiranya dapat menjadi salah satu alternatif bagi para pembaca untuk mengetahui gambaran dari tafsir karya Djohan Effendi, dan harapan kedepannya artikel ini juga dapat menumbuhkan ketertarikan dari para peneliti dan pengkaji tafsir, serta masyarakat pada umumnya atas karya tafsir tersebut.

\section{Pembahasan}

\section{Deskripsi dan Pengenalan Kitab Tafsir}

Esensi dan hakikat karya tafsir ini telah disampaikan oleh Djohan Effendi dalam kalimat pengatarnya. Bahwa Pesan-Pesan Al-Quran (yang bisa saja dipahami sebagai pesan mutlak dan mengikat) harus dibaca dan dipahami dengan anak judulnya, yaitu Mencoba Mengerti Intisari Kitab Suci. Kalimat 'mencoba mengerti' bermakna bahwa penafsiran Djohan dalam karya tersebut merupakan sebuah upaya mandiri darinya dalam mencoba memahami alQur'an. Kalimat tersebut tentu sekaligus menyiratkan kerendahan hati dari sang penulis, sebagaimana juga para mufassir pada umumnya yang tidak pernah mengklaim kebenaran atas penafsirannya. Secara tegas Djohan mengatakan pula bahwa yang dimaksudkan sebagai pesan-pesan al-Quran dalam karya ini berarti terbatas hanya pada pemahamannya yang jauh dari lengkap, tidak utuh, bersifat subjektif, relatif dan tidak final. Baginya, usaha menangkap pesan-pesan alQuran secara umum adalah sebuah proses pencarian yang tidak pernah sampai ke titik ujung, purna dan selesai. Hubungan seseorang dengan al-Qur'an, lanjutnya adalah bagaikan hubungan subjek dan objek yang bergerak dan tidak pernah berhenti. Bagian dari pergumulan seorang thâlib dan sâlik (pencari dan pejalan) yang berharap pencarian dan perjalanan hidupnya ditutup oleh hembusan nafas terakhir dengan ucapan lâ ilâha illallâh.

Dalam kalimat pengantar yang disampaikannya, Djohan mengulas dan memberikan penekanan pada beberapa hal: pertama, tentang hakikat penafsiran atau pemahaman atas al-Qur'an. Menjadi sebuah keniscayaan bahwa manusia dengan keterbatasannya tidak akan mampu memahami al-Qur'an secara utuh, dalam arti tidak ada penafsiran yang benar-benar mutlak dan sempurna. Bukti daripada hal ini tentu jelas ketika melihat beragamnya kitab tafsir yang ada, 
dengan pemahaman dan penafsiran yang berbeda-beda pula. Bahwa pemahaman manusia atas al-Qur'an itu bersifat relatif dan mengandung kemungkinan salah dan benar.

Kedua, Djohan menyoroti aspek bahasa, dimana seringkali terjadi perbedaan penerjemahan dan pemaknaan diantara para penafsir. Seperti contoh kata sariya dalam surah Maryam ayat 24. Djohan mengungkapkan perbedaan penerjemahan yang ada diantara para mufassir Indonesia seperti Mahmud Yunus yang mengartikannya sebagai ghulam yang mulia, kemudian H.B. Jassin menerjemahkannya dengan anak yang mulia, dan sebagainya. Contoh yang lain misalkan kata lâmastum an-nisâ' yang terdapat dalam surah an-Nisâ' ayat 43 dan al-Mâidah ayat 6. Perbedaan pemahaman dari Imam Syafi'i, Imam Hanafi dan Imam lainnya, berujung pada perbedaan istinbath hukum diantara para Imam tersebut. Beberapa kata lain juga disinggung oleh Djohan dengan model penjelasan yang sama, yaitu menunjukkan perbedaan penerjemahan dan pemaknaan dari para mufassir tentang beberapa kosakata al-Qur'an.

Bukan hanya menguraikan perbedaan pemaknaan dan penerjemahan dari para mufassir, Djohan dalam beberapa kesempatan juga menawarkan penerjemahannya sendiri. Diantaranya ketika menyinggung kata rabb, yang umumnya diterjemahkan sengan kata 'Tuhan'. Djohan juga menyebutkan penerjemahan kata rabb ini dari beberapa penafsir dan penerjemah seperti Quraish Shihab (memaknainya dengan sang pemelihara), Muhammad Asad (sustainer), Yusuf Ali (the cherisher and the sustainer), dan kemudian Djohan mengungkapkan pendapatnya sendiri. Bahwa kata rabb yang mengandung makna pencipta, pemilik, pengatur, penguasa, pendidik, penyedia rezeki, dan penjamin keamanan, jika dialihbahasakan ke dalam bahasa Indonesia, menurutnya kata yang tepat adalah Tuban Pelantan. Terjemahan tersebut berdasarkan pengamatannya, lebih mendekati karakter dari kata rabb yang ada dalam bahasa arab tersebut.

Begitu juga dengan kata rahmân dan rahîm yang kebanyakan diartikan dengan maha pengasih dan maha penyayang, Djohan memberikan arti tersendiri, yang berbeda dari penerjemah dan mufassir lainnya. Bahwa rahmân menurut terjemahannya bermakna yang maha pengasih bagi semua, sedang rahîm bermakna penganugerah ganjaran berlipat ganda. ${ }^{11}$

11 Perhatian dan ketertarikan Djohan terhadap pemaknaan dan pengalihbahasaan kosakata al-Qur'an ke dalam bahasa Indonesia ini, sejatinya lahir berdasarkan pengalamannya ketika menjadi sekretaris Tim Peneliti Terjemahan H.B Jassin; Al-Qur'an Bacaan Mulia. Dan sebagaimana diketahui bahwa terjemahan H.B Jassin juga bernuansa puitis. Hal ini dinyatakan pula oleh Djohan dalam kata pengantarnya “... Selama tiga tabun saya mendampingi Ustadz. Muchtar Luthfi (Ketua Tim Peneliti Terjemahan H.B. Jassin) selaku sekretaris beliau, kami membaca ayat demi ayat sambil mendiskusikan terjemahannya, dan kegiatan ini diulang sebanyak tiga kali. Kegiatan ini sangat 
Ketiga, selain penekanan pada hakikat penafsiran yang relatif, dan keragaman penerjemahan, Djohan juga menyinggung tentang perbedaan qiraat. Sebagai contoh, kata malakaini (dua malaikat) yang terdapat dalam surah al-A'râf ayat 20, - sementara qiraah sab'ah sepakat dengan redaksi tersebut- Djohan lebih cenderung pada bacaan dari salah satu qiraah asyrah yang membacanya dengan malikaini (dua raja). Adapun ayatnya sebagai berikut:

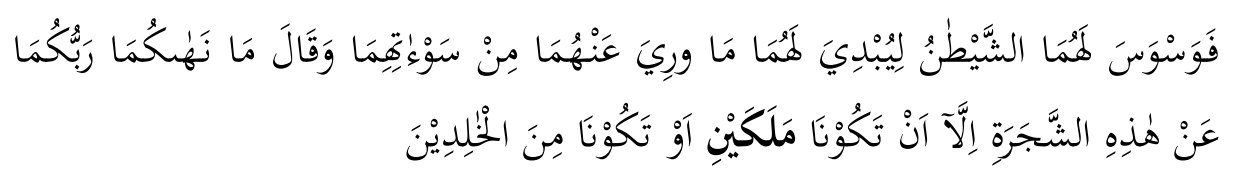

20. Kemudian setan membisikkan pikiran jahat kepada mereka agar menampak.kan aurat mereka (yang selama ini) tertutup. Dan (setan) berkata, "Tuhanmu banya melarang kamu berdua mendekati pohon ini, agar kamu berdua tidak menjadi malaikat atau tidak menjadi orang yang kekal (dalam surga).” Terjemah Kemenag 2002

Berdasarkan analisisnya, kata malikaini lebih tepat penggunaannya daripada malakaini, dengan alasan, jika menggunaan malakaini yang berarti malaikat, bagaimana bisa setan menggoda Adam dan Hawa dengan menjadi malaikat, padahal kedudukan malaikat lebih rendah darinya, dan bahkan malaikat bersujud kepadanya. Akan tetapi jika menggunakan kata malikaini yang berarti raja, maka ayat tersebut akan lebih masuk akal, karena memiliki kesesuaian dan keterkaitan dengan ayat 120 surah Tâhâ, yang berbunyi:

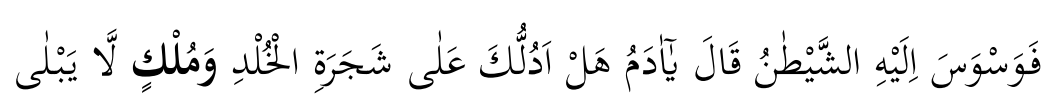

120. Kemudian setan membisikean (pikiran jahat) kepadanya, dengan berkata, "Wahai Adam! Maukah aku tunjukkan kepadamu pohon keabadian (khuldi) dan kerajaan yang tidak akan binasa?” Terjemah Kemenag 2002

Dua ayat diatas membicarakan kasus yang sama, sehingga akan tampak kesesuaian dan ketepatannya ketika ayat yang ada dalam surah al-A'râf tersebut beredaksi malikaini (dua raja) karena menjadi pasangan kata mulk (kerajaan) yang terdapat dalam surah Taha.

Dari tiga hal diatas; tentang keniscayaan relatifitas penafsiran, keragaman penerjemahan, dan perbedaan qiraat, yang disinggung Djohan dalam kata

berkesan dan bermakna bagi saya. Pengetabuan yang didukung oleh penghayatan beliau sebagai penutur bahasa Arab, dan kecermatan beliau dalam mengkritisi berbagai terjemahan dan tafsir al-Qur'an, memberikan pengetahuan yang sangat berharga kepada saya”. Djohan Effendi, Pesan-Pesan Al-Qur'an; Mencoba Mengerti Intisari Kitab Suci (Jakarta: Serambi, 2012), hlm. 25. 
pengantar bukunya dapat disimpulkan beberapa hal. Pertama, Djohan mempunyai ketertarikan tersendiri dalam aspek bahasa, khususnya pengalihbahasaan ke dalam bahasa Indonesia. Dan kedua, analisisnya pada kosa kata al-Qur'an dan perbedaan qiraat juga menunjukkan keluasan bacaan dan pengkajiannya terhadap al-Qur'an, paling tidak dalam dua permasalahan tersebut.

Setelah memberikan kata pengantar, Djohan beranjak pada muqaddimah atau pendahuluan. Kandungan al-Qur'an, yang dibahasakannya sebagai 'pesanpesan yang ada dalam al-Qur'an' dapat dilihat dalam dua perspektif; yaitu perspektif masa turunnya (berdasarkan urutan turunnya ayat pertama sampai dengan yang terakhir) dan perspektif susunan mushaf yang sekarang. Berdasarkan masa turunnya, pesan-pesan yang ada dalam al-Qur'an dapat dikelompokkan menjadi 3 berdasarkan periodenya, yaitu: periode MakkahPermulaan, periode Makkah-Kemudian dan periode Madinah. Setiap periode tersebut memiliki karakteristik dan penekanan tersendiri pada ayat-ayat dan surat-suratnya.

Sedangkan pesan-pesan al-Qur'an dari perspektif susunan mushaf, Djohan mengelompokkanya menjadi tiga, yaitu pembukaan, batang tubuh dan penutup. Adapun perincian daripada pembagian tersebut adalah sebagai berikut:

Tabel 1. Struktur Mushaf menurut Djohan Effendi

\begin{tabular}{|c|c|}
\hline Sistematika & Nama Surah \\
\hline Pembukaan (Prolog) & QS. Al-Fâtihah \\
\hline Batang Tubuh & $\begin{array}{l}\text { Ada } 11 \text { kelompok surat dalam batang tubuh: } \\
\text { 1. } 6 \text { Surah: al-Baqarah, Ali 'Imrân, an- } \\
\text { Nisầ, al-Mâidah, al-'An'âm, dan al- } \\
\text { A'râf } \\
\text { 2. } 9 \text { Surah: al-Anfâl, at-Taubah, Yûnus, } \\
\text { Hûd, Yûsuf, ar-Ra'd, Ibrahîm, al-Hijr, } \\
\text { dan an-Nahl. } \\
\text { 3. } 13 \text { Surah: al-Isrâ', al-Kahfi, Maryam, } \\
\text { Tâhâ, al-Anbiyâ', al-Haji, al- } \\
\text { Mu'minunn, an-Nûr, al-Furqân, asy- } \\
\text { Syu'ara, an-Naml, al-Qashash, dan al- } \\
\text { 'Ankabût. } \\
\text { 4. } 4 \text { Surah: ar-Rûm, Luqmân, as-Sajdah, } \\
\text { dan al-Ahzâb. } \\
\text { 5. } 6 \text { Surah: Saba', Fathîr, Yâ-Sîn, ash- } \\
\text { Shaffât, Shad, dan az-Zumar. } \\
\text { 6. } 7 \text { Surah: Ghâfir, Fushshilât, asy-Syûra, } \\
\text { az-Zukhrûf, ad-Dukhân, al-Jâtsiyah, }\end{array}$ \\
\hline
\end{tabular}




\begin{tabular}{|c|c|}
\hline & $\begin{array}{l}\text { dan al-Ahqâf. } \\
\text { 7. Surah: Muhammad, al-Fath, dan al- } \\
\text { Hujurât } \\
\text { 8. } 7 \text { Surah: Qaf, adz-Dzâriyat, ath-Thûr, } \\
\text { an-Najm, al-Qamar, ar-Rahman, dan } \\
\text { al-Wâqi'ah. } \\
\text { 9. } 10 \text { Surah: al-Hadîd, al-Mujâdalah, al- } \\
\text { Hasyr, al-Mumtahanah, ash-Shâf, al- } \\
\text { Jumu'ah, al-Munâfiqun, at-Taghâbun, } \\
\text { ath-Thalâq, dan at-Tahrîm. } \\
\text { 10. } 11 \text { Surah: al-Mulk, al-Qalam, al- } \\
\text { Haqqah, al-Ma'ârij, Nûh, al-Jinn, al- } \\
\text { Muzammil, al-Mudatstsir, al-Qiyâmah, } \\
\text { al-Insân, dan al-Mursalât. } \\
\text { 11. } 34 \text { Surat dimulai dari surah an-Nabâ' } \\
\text { sampai al-Lahab. }\end{array}$ \\
\hline Penutup (Epilog) & $\begin{array}{l}\text { Tiga surah terakhir, yaitu al-Ikhlâs, al-Falaq, } \\
\text { dan an-Nâs }\end{array}$ \\
\hline
\end{tabular}

Surat-surat diatas dikelompokkan berdasarkan penekanan tema dalam setiap surahnya. Menurut Djohan, urutan surah yang ada dalam mushaf tersebut sejatinya tidak bersifat acak begitu saja. Dibalik urutan yang ada tersebut terdapat alasan logis yang dapat dinalar dan dipahami, terutama jika dilihat dari tema-tema yang ditekankan dalam tiap-tiap surah. Sebagai contoh adalah 6 surah (surah Yûnus, Hûd, Yûsuf, ar-Ra'd, Ibrahîm, dan al-Hijr) yang sama-sama memiliki awalan huruf muqattha'b alim-lam-ra (kecuali surah ar-Ra'd dengan aliflam-mim-ra). Djohan menyebut 6 surah tersebut sebagai sebuah serial tersendiri yang berarti memiliki keterkaitan satu dengan yang lainnya. Kelompok surah ini menurutnya sama-sama mengemukakan persoalan-persoalan yang dihadapi terutama berkaitan dengan ancaman dari luar, hubungan dengan Tuhan dan tentu kisah para Nabi dengan umatnya. ${ }^{12}$

\section{Karakteristik Kitab Tafsir; Metode, Pendekatan dan Corak}

Al-Farmawiy dengan konsep 4 metode tafsirnya (tablîli, ijmâli, muqâran,

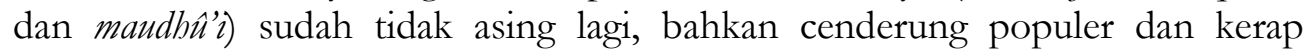
digunakan para peneliti Indonesia untuk mengkategorikan metode yang digunakan dalam sebuah karya tafsir. Beberapa ulama dan tokoh tafsir juga mendukung dan sependapat oleh al-Farmawiy, diantaranya adalah al-Kumy 
dalam kitabnya at-Tafsîr al-Maudhư $\hat{\imath}^{13}$, Abd as-Sattar Fathullah dalam kitabnya alMadkhal ila at-Tafsîr al-Maudhồ ${ }^{14}$, Fahd Abdurrahman dalam kitabnya Buhûts fì Ushâl at-Tafsir ${ }^{15}$, Nashruddin Baidan dalam bukunya Perkembangan Tafsir AlQur'an di Asia Tenggara ${ }^{16}$, dan lain sebagainya.

Kitab tafsir dengan tebal 500-an halaman yang ditulis oleh Djohan Effendi ini dalam penulisannya begitu terstruktur dan rapi. Meskipun hanya 500-an halaman, tetapi Djohan menafsirkan lengkap 30 juz. Sehingga model penyajian penafsiran secara ijmâli/global terlihat jelas dalam tafsirnya. Djohan menjelaskan makna-makna al-Qur'an dengan uraian singkat dan bahasa yang mudah sehingga dapat dipahami oleh semua orang baik yang berpengetahuan luas maupun orang awam. Djohan juga menafsirkan kata-kata al-Qur'an dengan kosakata yang ada dalam al-Qur'an sendiri, sehingga para pembaca yang melihat uraian tafsirnya tidak jauh dari konteks al-Qur'an, tidak keluar dari muatan makna yang dikandung oleh kosakata yang serupa dalam al-Qur'an, dan adanya keserasian antara bagian al-Qur'an yang satu dengan yang lain. ${ }^{17}$

Alasan lain yang menjadikan kitab tafsir ini tidak begitu tebal adalah karena tidak dituliskannnya ayat-ayat al-Qur'an. Bahkan tidak ditemukan satupun ayat dalam bahasa arab yang tertulis di dalamnya, kecuali hanya beberapa terjemahan saja dan kaligrafi potongan ayat. Jika saja Djohan menuliskan ayat-ayatnya lengkap 30 juz, tentu kitab tafsir ini bisa jadi dua kali lipat tebalnya.

Penyajiannya yang tematik surah juga menjadi alasan selanjutnya mengapa kitab tafsir ini tergolong tipis untuk ukuran penafsiran lengkap 30 juz. Namun sesuai dengan judul yang disematkannya, Djohan memang tidak menafsirkan seluruh ayat yang ada. Akan tetapi yang menjadi sorotan dalam tafsir ini adalah hanya tema-tema inti yang ada dalam setiap surah. Contohnya adalah ketika menafsirkan surat al-Baqarah, Djohan hanya mengambil 9 tema berdasarkan ayat-ayat yang ada dalam surah tersebut. Sembilan tema tersebut adalah 'al-Qur'an Kitab Hidayah', 'Muttaqin, Kafir, dan Munafik', 'Adam: Prototipe Manusia', 'Bani Israel: Sebuah Iktibar', 'Kecaman terhadap Eksklusifisme', 'Jangan Tiru Bani Israel', 'Ka'bah: Kiblat Baru Umat Islam',

\footnotetext{
${ }^{13} \mathrm{Ahmad}$ as-Sayyid Al-Kumy and Muhammad Ahmad Yusuf Al-Qasim, At-Tafsîr alMaudbû̀i li al-Qur'ân al-Karim, 1st edn (Kairo, 1982), h. 9.

${ }^{14} \mathrm{Abd}$ as-Sattar Fathullah Sa’id, Al-Madkhal ila at-Tafsîr al-Maudb̂̂̀i (Kairo, 1985), hlm. $16-17$.

${ }^{15}$ Fahd 'Abdurrahman bin Sumaiman Ar-Rumi, Bubûts fi Usbûl at-Tafsîr wa Manâbijubu (Riyadh: Maktabah at-Taubah), hlm. 57.

${ }^{16}$ Nashruddin Baidan and Erawati Aziz, Perkembangan Tafsir Al-Qur'an Di Asia Tenggara (Yogyakarta: Pustaka Pelajar, 2019), hlm. 26.

${ }^{17}$ Abdul Hayy Al-Farmawi, Metode Tafsir Maudhu'i Dan Cara Penerapannya, Terj. Rosihon Anwar, ed. by Maman Abd. Djaliel (Bandung: CV Pustaka Setia, 2002), hlm. 38.
} 
'Membangun Umat Berkualitas', dan 'Iman dan Do'a'. Begitu juga dalam surahsurah setelahnya, dengan model yang sama Djohan hanya mengambil beberapa tema saja untuk ditafsirkan.

Jika dapat disimpulkan sementara, berdasarkan uraian diatas, dan berdasarkan konsep 4 metode tafsir al-Farmawiy, maka penafsiran Djohan dalam karya tersebut termasuk menggunakan metode/model ijmâli yang sekaligus digabung dengan model tematik surah.

Adapun berdasarkan jenis pendekatan yang digunakan, yaitu: bil ma'tsûr, bil ra'yi, dan isyâri, kitab tafsir ini lebih condong pada pendekatan ra'yi/ijtihad. ${ }^{18}$ Meskipun juga terdapat beberapa riwayat hadis yang dikutip, yang tidak disebutkan secara langsung oleh Djohan dalam kitabnya tersebut. Hanya saja, kitab tafsir tersebut dapat digolongkan pada jenis 'tafsir terjemah', meskipun penerjemahannya tidak dilakukan secara literal dan kaku. Bentuk terjemahan yang dihidangkan Djohan adalah terjemahan yang dinarasikan, dan terjemahan yang dipuitisasi (terjemahan juz 30). Adapun corak/laun karya tafsir tersebut akan penulis bahas lebih jauh dalam sub bab selanjutnya.

Selain itu, terdapat beberapa hal yang unik daripada kitab tafsir karya Djohan Effendi ini. Diantaranya yaitu:

1. Model penulisan yang kekinian. Seperti halnya jurnal dan penelitian ilmiah lain yang memiliki sebuah abstrak dalam awal pembahasannya, kitab tafsir ini pun demikian. Djohan selalu memberikan Abstrak (laporan singkat dan general) pada setiap awal penafsirannya terhadap masing-masing surah yang ada. Sebagaimana juga posisi margin abstrak yang pada umumnya menjorok ke dalam, dalam kitab tafsir ini pun demikian.

Jumlah abstrak yang kesemuanya ada 114 abstrak, sesuai dengan total surah al-Qur'an tersbeut, Djohan begitu konsisten dalam menuliskan isi dan sistematika penulisannya. Hal-hal yang dituliskan Djohan dalam abstrak tersebut meliputi beberapa hal yaitu: nama surah, nama lain surah, nama surah sebelum dan sesudah surah itu sendiri (nu₹uli), arti surah, tempat turunnya, urutan surah (nuzuli dan mushafi), jumlah ayat, jumlah ruku', dan penjelasan singkat terkait hubungan antara isi surah dan nama surah, atau mendeskripsikan alasan mengapa dinamakan surah A atau B.

${ }^{18}$ Djohan secara tegas juga mengatakan bahwa karya tafsir tersebut merupakan hasil pemahaman pribadinya atas al-Qur'an, dengan bekal pengetahuan dan pengalamannya yang terbatas, tidak pula dimaksudkan untuk ditulis sebagai naskah akademis ataupun hasil dari sebuah kajian ilmiah. Lihat: Effendi, Pesan-Pesan Al-Qur'an..., hlm. 17. 
Selain itu, jika surahnya diawali huruf muqaththa'ât, Djohan pun pasti menyebutkannya di dalam abstrak. Adapun pendapat Djohan sendiri mengenai arti atau penafsiran daripada huruf-huruf muqaththa'ât tersebut adalah dengan mengatakan bahwa huruf tersebut berfungsi untuk menarik perhatian pembacanya pada pesan-pesan ilahiah yang akan disampaikan dalam surah tersebut. Dari beberapa surah yang berawalan huruf muqaththa'ât, Djohan konsisten dengan pendapat tersebut, meskipun disampaikan dengan bahasa yang berbeda-beda dalam setiap surahnya. Namun terdapat satu pengecualian dalam hal ini, yaitu ketika dalam surah Yâ-Sîn Djohan tidak mengatakan demikian. Djohan menjelaskan bahwa huruf muqaththa'ât Yâ-Sîn dipahami juga sebagai singkatan dari kata Yâ Insân (wahai manusia). Tapi manusia disini, jelasnya bukan sembarang manusia, tetapi manusia istimewa yaitu Rasulullah saw. Karena itu, perkataan Yâ-Sîn juga dianggap salah satu nama Nabi yang mencerminkan manusia berakhlak mulia, pembawa rahmat bagi seluruh kehidupan, dan teladan utama bagi umatnya.

2. Hal kedua yang unik daripada kitab tafsir ini adalah, selalu ditambahkannya puisi-qur'aniy pada setiap akhir surah. Sehingga total puisi yang ada adalah 114 puisi, ditambah dengan 34 terjemahan puitis juz 30 yang dicantumkannya dalam lampiran. Terkait dengan ini, Djohan mengatakan dengan jelas dalam pengantarnya bahwa puisi-puisi qur'aniy serta terjemahan puitik juz 30 tersebut dimaksudkan untuk mengingatkan bahwa al-Qur'an tidak cukup didekati hanya dengan rasio, tapi juga semestinya dengan rasa. Lanjutnya, justru dengan menghayati aspek puitik al-Qur'an, kedalaman keberagaman kita lebih tersentuh dan tergugah.

3. Ditambahkannya seni kaligrafi pada beberapa tempat dan surah, menjadi hal unik lainnya. Ada 12 tulisan kaligrafi dengan jenis berbeda yang ada dalam kitab tersebut. Satu dalam akhir kalimat pendahuluan, satu dalam akhir penjelasan basmalah, dan 10 lainnya tersebar dalam surah-surah; 3 surah awal (al-Fatihah, al-Baqarah, Ali Imran), tiga surah terakhir (al-Ikhlas, al-Falaq, anNas), dan 4 surah acak (al-Fath, al-A'la, al-Qadr, dan al-'Ashr). Tidak seperti dituliskannya puisi yang dia berikan alasan atas penulisannya, Djohan tidak menegaskan apa arti ditambahkannya kaligrafi tersebut dalam beberapa surah tersebut. Namun barangkali Djohan bermaksud untuk menampakkan kekayaan khazanah keilmuan dan kebudayaan Islam dalam bukunya, yang salah satunya adalah dengan adanya seni kaligrafi.

4. Selain penjelasan atau tafsiran al-Qur'an, Djohan juga mencantumkan lampiran yang berisi tulisan-tulisan ilmiahnya yang telah lalu. Ada 5 tulisan yang dicantumkannya dalam lampiran, dan kesemuanya bertemakan alQur'an, yaitu;

a. Penyempurnaan Diri Insan dalam Perspektif Al-Qur'an

b. Takdir dan Kebebasan dalam Perspektif Al-Qur'an 
c. Pluralisme Agama dalam Perspektif Al-Qur'an

d. Kaum Mustadhafin dalam Perspektif Al-Qur'an

e. Quranisme Versus Qarunisme

Penambahan tulisan-tulisan tersebut tentu tidak biasa ditemui dalam kitabkitab tafsir pada umumnya, terlebih kitab-kitab tafsir klasik. Sehingga hal tersebut menjadi salah satu ciri tersendiri dari kitab tafsir ini.

5. Djohan tidak pernah menyebut tafsir untuk mendeskripsikan bukunya. Daripada menyebut 'tafsir' atau 'kitab tafsir', Djohan lebih memilih menggunakan kata 'buku ini' dan 'tulisan ini'. Agaknya Djohan memang enggan menyebut karyanya ini sebagai sebuah karya tafsir sebagaimana umumnya.

\section{Teknik Penulisan Tafsir 'Pesan-Pesan Al-Quran'}

Sebagai sebuah penelitian yang berfokus pada literatur tafsir di Indonesia, tentu kurang absah jika mengabaikan kerangka paradigma tafsir di Indonesia yang dibuat oleh Islah Gusmian. Dalam bukunya 'Khazanah Tafsir Indonesia' Islah Gusmian telah memberikan sumbangan yang penting dalam kajian tafsir secara umum, dan khususnya dalam menggagas pemetaan karya tafsir Indonesia. ${ }^{19}$ Meskipun kerangka tersebut dibuat berdasarkan literatur kitab tafsir Indonesia pada dekade 90-an, namun kerangka tersebut secara general telah mewakili sebagian besar literatur kitab tafsir Indonesia secara keseluruhan, meskipun ada beberapa celah yang masih perlu dibahas. Sebagai contoh adalah posisi karya tafsir dengan model komparatif (muqâran), dimana dalam kerangka sistematika yang dibuat oleh Islah belum mencakup karya tafsir muqâran ini. Namun tentu ketiadaan tersebut karena memang tidak ditemukan karya tafsir muqaran pada dekade tahun tersebut.

Menurut Islah, setidaknya terdapat 10 hal yang perlu dikaji ketika hendak melakukan analisis karya tafsir, sebagai berikut: ${ }^{20}$

1. Sistematika Penyajian: Terdapat dua model sistematika penyajian, yaitu runtut dan tematik ${ }^{21}$, dengan perinciannya berikut:

19 Islah Gusmian, Khazanah Tafsir Indonesia; Dari Hermeneutika Hingga Ideologi (Yogyakarta: LKiS, 2013), hlm. 111.

${ }^{20}$ Gusmian, Khazanah Tafsir Indonesia..., hlm. 122.

${ }^{21}$ Pembagian ini senada dengan yang dikemukakan oleh 'Amr bin Salim dalam kitabnya, yang mengatakan bahwa terdapat dua macam penyajian tafsir ('ardh at-tafsir), yaitu attafsîr al-maudhii (runtut) dan at-tafsîr al-maudhồi (tematik). Lihat: Muhammad bin Amr bin Salim, Tabrîr at-Tafsîr al-Maudhû̀i wa al-Wabdah al-Maudhû̉iyyah li as-Sûrah (Makkah: Jami'ah Umm alQura), hlm. 11-12. Begitu juga Baqir Shadr yang membagi tafsir menjadi dua yaitu at-tafsîr at- 
a. Runtut, mencakup dua hal: 1) Runtut berdasarkan urutan mushaf, dan 2) Runtut berdasarkan urutan turunnya wahyu

b. Tematik, terdapat dua jenis tematik: 1) Tematik Klasik; adalah sistematika penyajian tafsir yang mengambil satu surah/juz tertentu dengan topik sebagaimana yang ada dalam surah/juz tersebut, 2) Tematik Modern; adalah menyajikan tafsir dengan mengacu pada sebuah tema yang telah ditentukan sebelumnya oleh sang mufasir.

Dalam sistematika penyajian tematik, terkadang mufassir hanya mengambil dan menentukan satu tema saja dalam penafsirannya (tematik singular), dan terkadang menafsirkan beberapa tema (tematik plural).

2. Bentuk Penyajian;

a. Bentuk Penyajian Global; tafsir disajikan dengan bahasa yang sederhana dengan uraian yang singkat sehingga mudah dipahami oleh pembaca

b. Bentuk Penyajian Rinci; bentuk penyajian tafsir yang menitikberatkan pada uraian-uraian penafsiran secara detail, mendalam dan komprehensif.

3. Gaya Bahasa Penulisan Tafsir

a. Gaya Bahasa Penulisan Kolom; penulisan tafsir menggunakan kalimat yang pendek, lugas, dan tegas.

b. Gaya Bahasa Penulisan Reportase; menggunakan kalimat yang sederhana, ilegan, komunikatif, dan lebih menekankan pada hal yang bersifat pelaporan dan bersifat buman interest.

c. Gaya Bahasa Penulisan Ilmiah; menggunakan bahasa yang formal dan ilmiah, sebagaimana penelitian ilmiah lainnya.

d. Gaya Bahasa Penulisan Populer; menempatkan bahasa sebagai medium komunikasi dengan karakter kebersahajaan.

4. Bentuk Penulisan Tafsir: a) Ilmiah, b) non-Ilmiah

5. Sifat Mufassir: a) Individual, b) Kolektif

6. Asal Usul dan Keilmuan Mufassir

7. Asal Usul Literatur Tafsir: a) Akademik, b) non-Akademik

8. Sumber-Sumber Rujukan: Sumber rujukan tafsir dapat dibedakan menjadi sumber rujukan yang berbahasa Arab, Bahasa Inggris, dan Bahasa Indonesia. Begitu juga sumber rujukan tafsir yang berasal dari Timur Tengah, Barat, dan lokal Indonesia. Kemudian digabung pula dengan kriteria karya tafsir klasik, modern, atau kontemporer. 
9. Nuansa Tafsir: a) Kebahasaan, b) Sosial Kemasyarakatan, c) Teologis, d) Sufistik, d) Nuansa Psikologis, e) dan lain-lain

10.Pendekatan Tafsir: a) Tekstual, b) Kontekstual

Dalam menganalisis metode yang digunakan dalam sebuah karya tafsir, para peneliti umumnya mencukupkan diri dengan menggunakan kerangka 4 metode tafsir al-Farmawiy. Namun senyatanya kerangka yang dibangun alFarmawiy dalam 4 metode tafsir nya belum dapat memberikan informasi yang akurat tentang karya tafsir itu sendiri. Hal ini ditegaskan Islah, bahwa dalam kerangka yang dibangunnya, al-Farmawiy tidak memberikan pemetaan yang tegas antara wilayah metode dan pemeataan tafsir serta teknik penulisan tafsir. ${ }^{22}$ Oleh karena itu Islah membuat kerangka yang lebih mendetail dengan meliputi banyak hal sebagaimana yang telah penulis uraiakan diatas. Adapun perinciannya sebagai berikut,

Tabel 2. Analisis karya tafsir ala Islah Gusmian

\begin{tabular}{|l|l|}
\hline $\begin{array}{l}\text { Sistematika Penyajian } \\
\text { Tafsir }\end{array}$ & $\begin{array}{l}\text { Runtut 30 juz (urutan mushaf) + Tematik } \\
\text { Klasik (plural), dimana dalam setiap surah } \\
\text { terdapat beberapa tema pilihan yang menjadi } \\
\text { inti pembahasan. }\end{array}$ \\
\hline Bentuk Penyajian Tafsir & Global \\
\hline $\begin{array}{l}\text { Gaya Bahasa Penulisan } \\
\text { Tafsir }\end{array}$ & Gaya Bahasa Penulisan Populer \\
\hline Bentuk Penulisan Tafsir & Non-Ilmiah \\
\hline Sifat Mufassir & Individual \\
\hline Keilmuan Penafsir & $\begin{array}{l}\text { Djohan berasal dari lingkungan akademik } \\
\text { (S1 Tafsir Hadis IAIN Sunan Kalijaga } \\
\text { Yogyakarta, S2, dan S3 di Australian } \\
\text { National University). } \\
\text { Karakter khas yang menempel pada diri }\end{array}$ \\
\hline
\end{tabular}

22 Gusmian, Khazanah Tafsir Indonesia..., hlm. 122.Beberapa ulama dan peneliti senyatanya memang membedakan antara ketiga hal tersebut, sebagaimana yang disampaikan Islah. Contohnya adalah Abd as-Sattar Fathullah yang memetakan tafsir ke dalam 4 hal: sejarah tafsir, sumber tafsir (bil ma'tsur dan bil ra'yı), metode tafsir (tahlîli, ijmâli, muqâran, dan maudhû'i), dan cara penyajian tafsir (maudhi'i dan maudhû̀i). Lihat: Abd as-Sattar Fathullah Sa'id, AlMadkhal Ila at-Tafsir al-Maudhu'i (Kairo, 1985), hlm. 14-18. Begitu juga Amr bin Salim Bazmul menguatkan pendapat Abd as-Sattar, Amr membedakan antara metode tafsir dan cara penyajian tafsir. Bahkan menurutnya, metode maudhû'i yang kebanyakan dipahami sebagai sebuah metode tafsir, menurutnya bukanlah sebuah metode, melainkan sebuah model penyajian tafsir, التفسبر الموضوعي طريقة عرض, ولبس طربقة التفسبر (tafsir maudhî̀i merupakan sebuah model penyajian tafsir, bukan sebuah metode tafsir). Lihat: Salim, Tabrîr at-Tafsîr al-Maudhî̉i..., hlm. 27. 


\begin{tabular}{|c|c|}
\hline & $\begin{array}{l}\text { Djohan adalah kuatnya sikap pluralis. } \\
\text { Karakter pluralis Djohan terbentuk karena } \\
\text { dirinya merupakan seorang yang lahir dalam } \\
\text { lingkungan keberagaman ayng kental, serta } \\
\text { menjadi aktivis Lintas Iman sejak muda. } \\
\text { Dalam perjalanan karirnya yang tidak boleh } \\
\text { terlupakan, Djohan juga adalah seorang } \\
\text { Birokrat, seorang peneliti utama Kemenag, } \\
\text { hingga pernah menjadi seorang Menteri } \\
\text { Sekretaris Negara pada tahun } 2000-2001 . .^{23}\end{array}$ \\
\hline Asal-usul Literatur Tafsir & Non-Akademik \\
\hline $\begin{array}{l}\text { Sumber-sumber Rujukan } \\
\text { Literatur Tafsir }\end{array}$ & $\begin{array}{l}\text { Rujukan dalam karya tafsir ini, didominasi } \\
\text { oleh karya tafsir modern, baik berbahasa } \\
\text { Arab, Inggris, maupun Indonesia, seperti At- } \\
\text { Tafsîr al-Wajî̀ karya Wahbah Zuhayli, Nahw } \\
\text { at-Tafsîr al-Mawdlî'i li Suwar al-Qur'ân karya } \\
\text { Muhammad al-Ghazali, Tafsîr Juz. 'Amma } \\
\text { karya Muhammad Abduh, Taysîr al-Karîm ar- } \\
\text { Rahmah fì Tafsîr Kalam al-Manân karya Abd } \\
\text { ar-Rahman bin Nashir as-Sa'di, Tafsîr al- } \\
\text { Qur'ân al-Azhîm karya Mahmud Syaltut, } \\
\text { Commentary on the Holy Qur'an karya Ghulam } \\
\text { Ahmad, Kandungan al-Fatihah karya Bahrum } \\
\text { Rangkuti, Sura al-Fatiha; the Opening of the Holy } \\
\text { Qurankarya Khwaja Kamal, Al-Qur'an dan } \\
\text { Maknanya karya M Quraish Shihab, Al- } \\
\text { Qur'anul Karim Bacaan Mulia karya H.B. } \\
\text { Jassin, dan lain sebagainya. } \\
\text { Sumber rujukan dalam karya tafsir ini sangat } \\
\text { berimbang, dengan merujuk pada karya tafsir } \\
\text { Timur Tengah, Barat, dan Lokal Indonesia. } \\
\text { Namun Djohan sama sekali tidak merujuk } \\
\text { pada karya tafsir klasik seperti Tafsîr ath- } \\
\text { Thabarî, Tafsîr Ibn Katsîr, Tafsîr al-Kasysyâf, dan } \\
\text { sebagainya. Hal ini wajar mengingat dalam } \\
\text { beberapa hal Djohan memang berseberang } \\
\text { paham dengan pendapat-pendapat ulama } \\
\text { tafsir klasik. }\end{array}$ \\
\hline
\end{tabular}

23 Ahmad Gaus AF, Sang Pelintas Batas: Biografi Djoban Effendi (Jakarta: ICRP, 2009).Lihat juga 'Djohan Effendi', Wikipedia<https://id.wikipedia.org/wiki/Djohan_Effendi> [accessed 2 June 2020]. 


\begin{tabular}{|c|c|}
\hline & $\begin{array}{l}\text { Sedangkan itu, sisi puitis Djohan yang } \\
\text { dituangkan dalam tafsirnya, sebagaimana } \\
\text { penulis sebutkan sebelumnya, kemungkinan } \\
\text { besar berhubungan dengan saat Djohan } \\
\text { menjadi sekretaris Tim Peneliti Terjemahan } \\
\text { H.B. Jassin; Al-Qur'an Bacaan Mulia, yang } \\
\text { pada dasarnya terjemahan H.B. Jassin } \\
\text { tersebut juga kental dengan puitisasi } \\
\text { terjemahannya. }\end{array}$ \\
\hline Nuansa Tafsir & Pluralis, Feminis, Puitis \\
\hline Pendekatan Tafsir & $\begin{array}{l}\text { Tekstual, karena pada dasarnya tafsir karya } \\
\text { Djohan Effendi ini lebih terlihat seperti } \\
\text { Tafsir Terjemah, dimana kalimat-kalimat } \\
\text { yang disajikannya tidak jauh berbeda dari } \\
\text { muatan terjemah ayat-ayat yang ada. } \\
\text { Perbedaannya dengan tafsir terjemah pada } \\
\text { umumnya adalah, penulisannya yang naratif } \\
\text { dan tidak kaku. Selain itu Djohan memang } \\
\text { juga menerjemahkan juz } 30 \text { secara puitis, } \\
\text { seperti yang dilampirkannya. Yang menarik } \\
\text { adalah bahwa model penyajiannya disajikan } \\
\text { dalam tema-tema yang ditentukan dalam } \\
\text { setiap surah, sehingga secara otomatis } \\
\text { Djohan tidak menerjemahkan seluruh ayat, } \\
\text { melainkan ayat-ayat yang terdapat hubungan } \\
\text { dengan tema yang ia tentukan. }\end{array}$ \\
\hline
\end{tabular}

\section{Kecondongan-Kecondongan Djohan Effendi dalam Tafsirnya}

Pada dasarnya, latar belakang sosial, pendidikan dan pergumulan keilmuan dari seseorang, itulah yang bisa memperlihatkan kecondongan seseorang terhadap sesuatu. Begitu juga dalam tafsir, setiap kitab tafsir pastinya mempunyai ciri dominan yang ada di dalamnya, dimana ciri tersebut tidak lain berhubungan dengan latar belakang keilmuan dari sang mufassir tersebut. Ciri ini kemudian dalam kajian tafsir disebut dengan laun/corak. Dalam kajian tafsir dikenal beberapa corak seperti lughawi, fighi, 'ilmi, falsafi, tarbawi, sufi, dan adabi ijtima’i.

Apabila mengacu pada macam-macam corak diatas, kitab tafsir karya Djohan Effendi ini tidak dapat digolongkan pada salah satunya. Sebaliknya, kitab tafsir ini memiliki corak atau kecenderungan tersendiri di dalamnya, yaitu sebagai berikut: 


\section{Pluralis}

Dalam beberapa kesempatan, Djohan selalu menekankan semangat pluralitas dalam beragama. Diantaranya adalah dalam surah al-Baqarah, salah satu tema yang diangkat dalam tafsiran surah tersebut adalah 'Membangun Umat Berkualitas'. Dibagian akhir tema tersebut Djohan berkata,

Prinsip yang harus dibayati umat Islam adalah prinsip kebebasan beragama, sebab nilai keberagamaan terletak. pada ketulusan dan bukan karena keterpaksaan dan kepura-puraan. Prinsip kebebasan beragama dan berkeyakinan bersifat sangat mendasar bagi manusia sebagai makbluk yang mengemban amanat kekhalifahan di muka bumi agar tidak berlaku dralim. ${ }^{24}$

Selanjutnya, dalam dua surah yaitu al-Mâidah dan al-An'am, Djohan membuat tema yang sama dengan judul 'Jangan Berlebihan', dimana dalam keduanya ditekankan hal yang sama, yaitu semangat pluralitas beragama. Sebagaimana yang dikatakan Djohan berikut,

Dan sekali lagi diingatkan bahwa sikeap tidak berlebib-lebihan ini sangat penting, tidak hanya dalam hal makanan, tetapi juga dalam beragama. Penegasan bahwa banya Tuhan sendiri yang lebih tahu siapa yang sesat dan siapa yang mengikuti petunjuk agaknya tidak terlepas dari peringatan untuk tidak berlebih-lebihan sehingga orang terjebak dalam praktik sesat-menyesatkan. ${ }^{25}$

Djohan juga mengangkat tema 'Keragaman adalah Ujian' dalam menafsirkan bagian akhir surat Hûd. Bahwa keragaman yang ada merupakan batu uji siapakah ang paling baik perbuatannya. Sehingga tugas utama masingmasing dari kita meskipun berbeda-beda agama, suku, budaya dan lainnya, adalah memegang kejujuran dan konsisten melakukan amal kebajikan.

Semangat jiwa pluralis Djohan lebih jelas terlihat ketika Djohan mengangkat tema 'Kebenaran dan Kebebasan Berkeyakinan' dalam menafsirkan surat al-Kahfi. Kisah pemuda ashâbul kabfi digambarkannya sebagai sebuah kisah menyangkut ketidakbebasan beragama. Lanjutnya, surah al-Kahfi ini menekankan bahwa kebenaran berasal dari Tuhan namun manusia diberi kebebasan penuh untuk menerimanya ataukah menolaknya. Tegas Djohan mengatkan bahwa 'tak ada orang atau lembaga apapun yang mempunyai wewenang untuk memaksakan seseorang untuk memeluk atau tidak memeluk keyakinan tertentu. Keberagaman yang tulus menghendaki kebebasan yang penub untuk. menentukan piliban, percaya atau tidak, beriman atau bersikap kufur'. Hanya saja, kebebasan tersebut seimbang dengan konsekuensi-konsekuensi dan tanggung jawab yang melekat pada pilihan yang diambil manusia, tutup Djohan dalam penjelasannya. ${ }^{26}$

\footnotetext{
${ }^{24}$ Effendi, Pesan-Pesan Al-Qur'an..., 62.

${ }^{25}$ Effendi, Pesan-Pesan Al-Qur'an..., hlm. 88.

${ }^{26}$ Effendi, Pesan-Pesan Al-Qur'an..., hlm. 144.
} 
Dalam surah al-Haji, dalam judul tema 'Pulangkan Perbedaan kepada Allah', Djohan menekankan sekali lagi bahwa keberagaman yang ada seringkali membuat orang terjerumus ke dalam perselisihan bahkan permusuhan. Maka hendaknya manusia tidak perlu mempersoalkan hal itu, dengan menyerahkan keragaman hanya kepada Tuhan, karena hanya Tuhan sendirilah yang berhak memutuskan perselisihan mereka kelak di Hari Akhir. ${ }^{27}$ Dan masih dalam surah yang sama, Djohan mengangkat tema serupa dengan judul 'Keragaman Tidak Mungkin Dihilangkan', dengan penjelasan yang tidak jauh berbeda dengan sebelumnya. ${ }^{28}$

Dalam surah asy-Syûra, Djohan kembali mengangkat tema pluralitas dengan judul 'Keragaman adalah Kehendak Tuhan'. Djohan menjelaskan bahwa kebinekaan umat manusia adalah kehendak Tuhan, dan kehadiran mereka yang menolak dan menentang ajaran ke-Esa-an Tuhan yang dibawa oleh para Nabi tidak lain juga adalah bagian dari kebinekaan itu sendiri. Lanjutnya, surah asySyûra ini salah satunya berisi tentang penegasan bahwa kenyataan keberagaman itu diluar kontrol seorang Nabi, terlebih umat manusia pada umumnya. ${ }^{29}$

Selain itu, Djohan juga melampirkan tulisan ilmiah yang berjudul 'Pluralisme Agama dalam Perspektif al-Qur'an'. Tulisan tersebut secara tidak langsung telah merangkum penafsiran-penafsirannya mengenai pluralisme dalam al-Qur'an diatas.

Adapun kecondongan sikap pluralis Djohan dalam penafsirannya seperti yang telah penulis kemukakan diatas, tentu tidak lahir begitu saja. Akan tetapi bangunan pemikiran dan kiprahnya di masyarakat yang terbentuk selama masa masa hidupnya, sejak kecil hingga remaja dan dewasa, itulah yang memunculkan kecondongan tersebut.

\section{Feminis}

Sudah menjadi rahasia umum, bahwa dalam literatur tafsir klasik, pemaknaan terhadap ayat-ayat feminis seringkali mengalami bias penafsiran . Semisal dalam ayat arrijâlu qawwâmûna ala an-nisâ'..., Ibn Katsir dan azZamakhsyari dalam tafsirnya memaknai ayat tersebut sebagai ayat yang menunjukkan keunggulan laki-laki atas perempuan. ${ }^{30}$ Bahkan tugas keagamaan seperti adzan, khutbah, imam, dan sebagainya dianggap sebagai kelebihan lakilaki atas perempuan. ${ }^{31}$

${ }^{27}$ Effendi, Pesan-Pesan Al-Qur'an..., hlm. 162.

${ }^{28}$ Effendi, Pesan-Pesan Al-Qur'an..., hlm. 164.

${ }^{29}$ Effendi, Pesan-Pesan Al-Qur'an..., hlm. 240.

${ }^{30}$ Ismail bin Amr bin Ibn Katsir, Tafsîr al-Qur'ân al-Adżîm, Juz II, 2nd edn (Riyâdh: Dâr at-Tayyibah, 1999), hlm. 292.

${ }^{31}$ Az-Zamakhsyari, Tafsîr al-Kasysyâf an Haqâiq at-Tanzîl wa 'Uyûn al-Aqâwil fi Wujûh atTa'wîl, 3th edn (Beirut: Dâr al-Ma'rifah, 2009), hlm. 234. 
Sebagian ulama Indonesia (khususnya ulama Islam tradisional) masih merujuk dan berpedoman juga pada pendapat mufassir klasik diatas dalam menyikapi realitas kehidupan yang sekarang. Padahal dilain sisi perbedaan masa dengan segala perubahannya, termasuk peran perempuan di zaman ini menunjukkan sebuah perubahan yang sama sekali berbeda dari zaman Islam klasik.

Adapun Djohan dalam tafsirnya lebih condong untuk mengangkat dan menyuarakan hak-hak perempuan serta kesetaraan kedudukannya dengan lakilaki. Sebagai contoh adalah ketika Djohan memberikan penjelasan tentang ayat saksi dalam masalah utang-piutang (QS. Al-Baqarah/2: 282),

Dalam masalah utang-piutang diajarkan agar hal itu dilakukakan dengan cermat dan dicatat dengan teliti agar tidak terjadi sengketa. Menarik untuk ditekankan babwa transaksi perdata seperti ini tidak ekshusif hanya dilakukan oleb laki-laki terpisah dari perempuan, sebab juga disebutkan kemungkinan perempuan menjadi saksi dalam transaksi semacam ini. Menjadi seorang saksi bagi perempuan dalam masalah transaksi tidak mungkin terjadi kalau mereka bidup terkungkung dalam rumah. Karena itu, perempuan bukan sekadar makbluk. domestik, bidup terkurung dan terisolasi dari pergaulan dan kebidupan di luar rumah. Perempuan tidak. terlarang untuk menjadi tokoh publik. ${ }^{32}$

Begitu juga ketika sebagian mufassir memaknai ayat pertama surat anNisâ' sebagai penciptaan Hawa yang berasal dari tulang rusuk Adam, Djohan tidak sepaham dengan pendapat tersebut. Djohan condong kepada pendapat yang mengatakan bahwa Adam dan Hawa sama-sama tercipta dari jiwa dan jenis yang sama (min nafs wâhidah). Dimana konsekuensi dari hal itu adalah mengisyaratkan kesetaraan laki-laki dan perempuan karena keduanya sejenis dan seasal.

Perempuan tidak diciptakan dari tulang rusuk laki-laki sehingga kedudukannya berbeda dan berada di bawah laki-laki. Kesadaran akan kesetaraan dan persamaan serta ikatan persaudaraan umat manusia ditekankan karena dalam kehidupan bersama, manusia tidak. mungkin bidup sendirian yang terlepas dari kebidupan dan pergaulan bersama. Manusia saling memerlukan, saling tergantung, dan karena itu semestinya saling mendukung satu sama lain. ${ }^{33}$

Lebih jelas lagi adalah ketika Djohan menafsirkan ayat yang biasa digunakan sebagai legitimasi keunggulan laki-laki atas perempuan, yaitu ayat 34 surat an-Nisâ', sebagai berikut;

Laki-laki sebagai suami adalah adalah penopang keluarga, terutama istri dan anakanaknya, bukan sebagai penguasa yang bertindak mengungkung dan menghambat

${ }^{32}$ Effendi, Pesan-Pesan Al-Qur'an..., hlm. 61.

${ }^{33}$ Effendi, Pesan-Pesan Al-Qur'an..., hlm. 75. 
karir mereka. Istri juga berbak mempunyai bisnis dan penghasilan sendiri. Begitu juga martabat dan kehormatan perempuan harus dijunjung tinggi dan mereka tidak boleh dituduh tidak senonoh tanpa kesaksian yang tak terbantabkan. ${ }^{34}$

Senada dengan penafsiran diatas, dalam surah al-Mujâdalah Djohan mengangkat tema 'Perlakukan Istri dengan Baik' sebagai tema pertama dalam surah ini. Di dalamnya Djohan menjelaskan bahwa surah ini memberikan penghargaan yang tinggi terhadap seoarng istri bahwa dia tidak akan bersedia menerima untuk diperlakukan sewenang-wenang oleh sang suami, tidak bisa diceraikan begitu saja tanpa hak membela diri, atau dibiarkan terlunta-lunta dan tidak jelas nasibnya. Lanjutnya, tindakan yang memperlakukan istri sewenangwenang apalagi melakukan kekerasan, dianggap sebagai tindakan menentang Allah dan Rasulnya. Perlakuan yang bersifat menghina perempuan akan diberi balasan yang setimpal dan mereka yang melakukan penghinaan akan diperhinakan. ${ }^{35}$

Kecondongan Djohan pada feminisme dalam tafsirnya, selain buktibukti diatas, akan lebih terang lagi terlihat ketika Djohan menafsirkan surah atTakwir dengan mengangkat tema 'Ramalan tentang Zaman Modern'. Dimana menurutnya, salah satu ramalan tentang zaman modern adalah adanya kesadaran gender dan gerakan emansipasi kaum perempuan yang semakin merata. Puisi yang dihidangkan dalam menutup penafsiran surat at-Takwir tersebut juga adalah puisi bertemakan feminisme, dengan judul 'Emansipasi'. ${ }^{36}$

Dalam puisi yang lain, yaitu yang dituliskannya di akhir surah an-Nisâ', Djohan juga menyajikan puisi yang mengangkat harkat dan martabat perempuan. Puisi tersebut berjudul 'Ratu Dunia', yang dimaksudkan bahwa perempuan, khususnya seorang Ibu itulah ratu dunia, dimana anak harus berbakti kepadanya. Dalam puisi tersebut pula Djohan menyinggung Adam yang kesepian dan memerlukan Hawa sebagai pendamping. Dimana kehadiran Hawa bukan sekadar pelengkap, bukan juga jelmaan dari tulang iga, tetapi adalah mitra setara, yang berasal dari jenis yang sama, saling mendukung dan saling menjaga tanpa dominasi. Puisi tersebut disajikan Djohan dengan pemilihan diksi yang apik.

3. Puitis

Hal terakhir yang patut menjadi sorotan dari karya tafsir Djohan Effendi adalah terdapatnya puisi yang tidak kurang dari 100 puisi, atau lebih tepatnya 148 puisi termasuk terjemahan puitis juz 30. Dengan jumlah total halaman karya tafsir Djohan yang berjumlah 430 halaman (murni penafsiran), dan 544 halaman

\footnotetext{
${ }^{34}$ Effendi, Pesan-Pesan Al-Qur'an..., hlm. 76.

${ }^{35}$ Effendi, Pesan-Pesan Al-Qur'an..., hlm. 293.

${ }^{36}$ Effendi, Pesan-Pesan Al-Qur'an..., hlm. 357-358.
} 
(ditambah 5 tulisan ilmiah), berbarengan dengan puisi yang berjumlah 147 butir, dimana rata-rata puisi tersebut menempati satu halaman, maka dapat dipahami bahwa Djohan termasuk orang yang puitis. Kepuitisannya tersebut kemudian dituangkan dalam tafsirnya, sehingga tafsir karya Djohan ini pun pada akhirnya memiliki karakteristik tersendiri yang berbeda dari karya tafsir lainnya, salah satunya yaitu terdapat puisi-puisi yang terinspirasi dari ayat-ayat al-Qur'an. Atau kemudian yang penulis sebut sebagai puisi qur'aniy. Berikut adalah salah satu contoh puisi yang mengiringi surah al-Mầûn,

\author{
Pendusta Agama \\ Pendusta Agama! Siapa dia? \\ Apakah si ateis yang tak percaya Tuban \\ Ataukah penolak agama yang dibawa $\mathrm{Nabi}$ \\ Ataukah si munafik yang pura-pura beriman? \\ Tidak! \\ Dia yang tak peduli derita si miskin yang menderita \\ Anak-anak yatim yang bidup terlunta-lunta \\ Walau shalat tak ketinggalan \\ Tapi Cuma gerak dan ucapan \\ Hampir tak bermakna \\ Dan sia-sia
}

Dalam puisi diatas terlihat jelas bagaimana kandungan isi surah al-Mầûn tergambar didalamnya. Bukan tidak lain karena memang puisi tersebut terinspirasi dari surah al-Mâ'ûn itu sendiri. Selain puisi qur'aniy, yang tidak kalah menarik juga adalah terjemahan puitik juz 30 yang dihadirkan Djohan. Sebagai contoh, berikut terjemahan puitik surah al-Lahab,

\title{
Nyala Api \\ (Al-Masad)
}

Binasa tangan Abu Lahab, sungguh binasa dia

Harta dan usahanya sedikit pun ta' memberi guna

Akan dicampakkan dia ke dalam api menyala

Juga istrinya yang membawa kayu bakar

Pada lehernya jerat tali sabut melingkar

\section{Kesimpulan}

Mengacu pada pembagian 4 metode tafsir menurut al-Farmawiy, secara sederhananya karya tafsir Djohan Effendi termasuk menggunakan metode ïmali yang digabungkan dengan metode tematik surah. Namun karya tafsir ini dapat pula tergolong ke dalam jenis tafsir-terjemah mengingat Djohan juga menerjemahkan juz 30 secara puitis. Adapun kecondongan utama yang terlihat di dalamnya adalah penafsirannya yang pluralis, dimana terlihat Djohan cukup 
sering mengangkat tema kebebasan beragama dalam beberapa surah. Wajar, mengingat latar belakang pemikiran Djohan yang memang penuh dengan pembelaan terhadap umat beagama yang tertindas. Begitupun feminisme dan kesetaraan gender yang menjadi salah satu agenda dan wacana masyarakat modern-kontemporer juga tidak luput dibahas oleh Djohan, bahwa perempuan tidak lebih rendah dariapda laki-laki, baik dari asal penciptannya maupun peran yang dimainkannya. Bahkan Djohan mengangkat derajat perempuan dengan beberapa puisi yang disertakannya. Selain itu, pilihan bahasa dan kosakata yang dihadirkan Djohan dalam menyampaikan tafsirnya terlihat jelas akan puitisasinya. Didukung pula dengan dibubuhkannya puisi-qur'aniy dalam setiap akhir surah yang dibahas; dan begitu juga dengan terjemahan puitis juz 30 yang dilampirkannya. Tiga kecondongan dan karakteristik tersebut, yaitu pluralis, feminis, dan puitis, menjadikan karya tafsir Djohan Effendi ini sebagai sebuah karya tafsir yang unik dan berbeda dari karya tafsir lainnya, baik yang berasal dari Timur Tengah maupun lokal Indonesia sendiri. Sehingga kehadirannya sebagai sebuah karya tafsir yang menghiasi perkembangan tafsir di Indonesia patut diberikan apresiasi tersendiri.

\section{Bibliografi}

Adz-Dzahabi, Muhammad Husain, At-Tafsì Wa Al-Mufassirûn (Kairo: Maktabah Wahbah, 1976)

AF, Ahmad Gaus, Sang Pelintas Batas: Biografi Djohan Effendi (Jakarta: ICRP, 2009)

Al-Farmawi, Abdul Hayy, Metode Tafsir Maudhu'i Dan Cara Penerapannya, ed. by Maman Abd. Djaliel (Bandung: CV Pustaka Setia, 2002)

Al-Kumy, Ahmad as-Sayyid, and Muhammad Ahmad Yusuf Al-Qasim, AtTafsîr al-Maudhûi li al-Qur'an al-Karim, 1st edn (Kairo, 1982)

Ar-Rumi, Fahd 'Abdurrahman bin Sumaiman, Bubûts fi Ushûl at-Tafsir wa Manâhijubu (Riyadh: Maktabah at-Taubah)

As-Shadr, Muhammad Baqir, Al-Madrasah al-Qur'aniyyah (Kairo: Dar al-Kitab alIslami)

Az-Zamakhsari, Tafsir Al-Kasysyâf an Haqâiq at-Tanzîl wa 'Uyûn al-Aqâwil fi Wujûh at-Ta'wnil, 3th edn (Beirut: Dar Al Ma'rifah, 2009)

Baidan, Nashruddin, and Erawati Aziz, Perkembangan Tafsir Al-Qur'an Di Asia Tenggara (Yogyakarta: Pustaka Pelajar, 2019)

'Djohan Effendi', Wikipedia<https://id.wikipedia.org/wiki/Djohan_Effendi> [accessed 2 June 2020]

Effendi, Djohan, Pesan-Pesan Al-Qur'an; Mencoba Mengerti Intisari Kitab Suci (Jakarta: Serambi, 2012) 
Faizin, Hamam, and Arsyad Sobby Kesuma, 'Pemikiran Tafsir Djohan Effendi', Kalam, $\quad 11.2 \quad$ (2017), 455-88 $<$ https://doi.org/10.24042/klm.v11i2.1360>

Federspiel, Howard M., Popular Indonesian Literature of the Qur'an (New York: Cornell Modern Indonesia Project, 1994)

Gusmian, Islah, Khazanah Tafsir Indonesia; Dari Hermeneutika Hingga Ideologi (Yogyakarta: LKiS, 2013)

Hanik, Umi, 'Pluralisme Agama Di Indonesia', Jumal Pemikiran Keislaman, 25.1 (2014), 44-63 < https://doi.org/10.33367/tribakti.v25i1.154>

Hasan, Akhmad Muawal, 'Djohan Effendi Dan Warisan Islam Yang Toleran', Tirto.Id, $2018<$ https://tirto.id/djohan-effendi-dan-warisan-islam-yangtoleran-cKYk>

Johns, Anthony H., 'Qur'anic Exegesis in the Malay World: In Search of a Profile', in Approaches to the History of the Interpretation of the Qur'an, ed. by Andrew Rippin (Oxford: Clarendon Press, 1988)

Katsir, Ismail bin Amr bin Ibn, Tafsîr al-Qur'ân al-Ad₹îm, Juz II, 2nd edn (Riyadh: Dar at-Tayyibah, 1999)

Ma'afi, Rifat Husnul, and Alvin Qodri Lazuardy, 'Concept of Religious Pluralism According To Djohan Effendi', YAQZHAN: Analisis Filsafat, Agama Dan Kemanusiaan, 5.2 (2019), 87-102 < https://doi.org/https://doi.org/10.24235/jy.v5i2.5708>

Rahmawati, Evi, 'Membaca "Pesan-Pesan Al-Qur'an" Karya Djohan Effendi', Islam Lib, 2012 <http://islamlib.com/kajian/quran/membaca-pesanpesan-al-quran-karya-djohan-effendi/>

Riddell, Peter G., 'Abdurra'uf Al-Sinkili's Tarjunān Al-Mustafìd: A Critical Study of His Treatment of Juz 16' (Australia Natoinal University, 1984)

— - 'Earliest Quranic Exegetic Activity in the Malay Speaking States', Archipel, $\quad 38.1 \quad$ (1989), 107-24 <https://doi.org/10.3406/arch.1989.2591>

Rohman, Umi Nuriyatur, 'Tafsir Surah Al-Fatihah (Telaah Atas Pesan-Pesan Al-Qur'an: Mencoba Mengerti Intisari Kitab Suci Karya Djohan Effendi)', Jumal Ilmu Al-Qur'an Dan Hadist, 1.2 (2018), 211-38 $<$ https://doi.org/10.1017/CBO9781107415324.004>

Sa’id, Abd as-Sattar Fathullah, Al-Madkhal ila at-Tafsîr al-Maudhû̀i (Kairo, 1985)

Salim, Muhammad bin Amr bin, Tahrîr at-Tafsîr al-Maudhû̀i wa al-Wabdah alMaudbû'iyyah li as-Sûrah (Makkah: Jami’ah Umm al-Qura)

Surahman, Cucu, 'Pergeseran Pemikiran Tafsir Di Indonesia: Sebuah Kajian Bibliografis', Afkaruna, $10.2 \quad$ (2014), 217-32 <https://doi.org/10.18196/AIIJIS.2014.> 